УДК 336.24:339.543

DOI: https://doi.org/10.37320/2415-3583/9.26

Менліосманов 3.T.

аспірант кафедри податкової політики, Університет державної фіскальної служби України ORCID: https://orcid.org/0000-0002-4980-6334

\title{
АНАЛІЗ ТА КОНТРОЛЬ ПОДАТКОВИХ НАДХОДЖЕНЬ ДО БЮДЖЕТУ УКРАЇНИ ВІД ЗОВНІШНЬОЕКОНОМІЧНОЇ ДІЯЛЬНОСТІ
}

Відновлення сочіально-економічного потениіалу Украӥни та ї̈ фінансової стабільності залежить від зваженоі бюджетної політики та своєчасного наповнення державної скарбниці податками. Майже половину бюджетних надходжень становлять податки від зовнішньоторговельної діяльності. У статті проаналізовано структуру зовнішньоекономічної діяльності, сучасний стан зовнішньоторговельної діяльності, оцінку показників зовнішньоторговельного балансу, оцінку рівня відкритості начіональної економіки за останні роки. Висвітлено тенденції розвитку операцій з імпорту товарів та надходжень митних податків і платежів до державного бюджету. Розкрито основні показники ефективності митного контролю в частині формування додаткових платежів до бюджету від коригування митної вартості. Запропоновано змінити підходи до формування й реалізацї митноі політики на основі вдосконалення організачії митного контролю та посилення контрольної функиії з одночасним збереженням заходів, спрямованих на спрощення митних прочедур.

Ключові слова: зовнішньоторговельна діяльність, імпорт товарів, зовнішньоторговельний баланс, митні податки та платежі, митний контроль.

Постановка проблеми. Сучасні умови господарювання тісно пов'язані зі здійсненням зовнішньоекономічної діяльності (далі - ЗЕД), що виступає вирішальним чинником входження країни до глобалізованого економічного простору. Саме ЗЕД забезпечує, з одного боку, формування експортного потенціалу держави та надходження валютних коштів до країни, 3 іншого- забезпечення податкових надходжень від операцій 3 імпорту товарів, а також зміцнення світогосподарських зв'язків та формування сприятливого інвестиційного клімату в країні. Ефективність ЗЕД значною мірою залежить від вироблення, прийняття та реалізації зважених рішень у сфері формування митної політики, спрямованої на вдосконалення процедур митного регулювання. Зараз особливої уваги заслуговують питання формування й реалізації прозорих, зрозумілих і досяжних для суб'єктів ЗЕД правил і процедур у сфері оподаткування митними податками та платежами для забезпечення достатніх фінансових надходжень до казни держави. Водночас важливо не лише сформувати такі правила і процедури, а й контролювати їх виконання учасниками ЗЕД, що актуалізує роль митного контролю та вимагає його подальшого вдосконалення.

Аналіз останніх досліджень і публікацій. Результати наукових досліджень проблем розвитку ЗЕД та оподаткування у цій сфері знайшли відображення у працях багатьох учених, зокрема: О. Борисенко, І. Бураковського, С. Войцещука, I. Гуцула, А. Гальчинського, О. Гребельника, Т. Єфименко, Л. Івашової, І. Карамбовича, А. Крисоватого, Т. Ліпіхіної, І. Луценко, І. Лютого, В. П'ятницького, Н. Ситник, А. Соколовської,
А. Філіпенка та ін. Проте окремі положення щодо ефективності митного оподаткування експортноімпортних операцій та підвищення ролі інституту митного контролю й визначення шляхів його розвитку потребують подальшого дослідження.

Мета статті полягає в аналізі сучасного стану обсягів та показників з оподаткування операцій у сфері зовнішньоекономічної діяльності України та оцінюванні ефективності системи митного контролю щодо забезпечення повноти сплати митних податків та платежів суб'єктами ЗЕД.

Виклад основного матеріалу. Відповідно до Закону України від 16 квітня 1991 р. «Про зовнішньоекономічну діяльність» [1], зовнішньоекономічна діяльність - діяльність суб'єктів господарської діяльності України та іноземних суб'єктів господарської діяльності, побудована на взаємовідносинах між ними, що має місце як на території України, так і за їі межами (п. 8 ст. 1). Найбільш поширеними видами зовнішньоекономічної діяльності України, що підпадають під статистичні спостереження, є зовнішньоторговельна діяльність та фінансові операції у вигляді прямих іноземних інвестицій в Україну та з України. При цьому, як видно з табл. 1, зовнішня торгівля товарами є превалюючим видом ЗЕД і займає понад $80 \%$ від загальної суми зовнішньоекономічного обороту держави.

Окрім того, зауважимо, що прямі інвестиції та зовнішньоекономічні послуги є специфічними видами зовнішньоекономічної діяльності, які не проходять митного контролю й на які не оформлюються митні декларації, тому у межах даної роботи зосередимося на особливостях здійснення зовнішньоторговельних операцій із товарами, їх 
Таблиця 1 - Структура зовнішньоекономічної діяльності за 2010-2018 рр.

\begin{tabular}{|c|c|c|c|c|c|c|c|}
\hline \multirow{2}{*}{ Роки } & \multicolumn{2}{|c|}{ Обсяги в ЗЕД за видами, млн дол. США } & \multicolumn{3}{c|}{ Частка в ЗЕД від, \% } \\
\cline { 2 - 8 } & $\begin{array}{c}\text { Прямі } \\
\text { інвестицій }\end{array}$ & $\begin{array}{c}\text { Торгівля } \\
\text { товарами }\end{array}$ & $\begin{array}{c}\text { Торгівля } \\
\text { послугами }\end{array}$ & $\begin{array}{c}\text { Всього } \\
\text { ЗЕД }\end{array}$ & інвестицій & $\begin{array}{c}\text { торгівлі } \\
\text { товарами }\end{array}$ & $\begin{array}{c}\text { торгівлі } \\
\text { послугами }\end{array}$ \\
\hline 2010 & 6530,7 & 112147 & 17358 & 136036 & 4,8 & 82,4 & 12,8 \\
\hline 2011 & 6124,6 & 151002 & 20395 & 177522 & 3,5 & 85,1 & 11,5 \\
\hline 2012 & 5953,0 & 153548 & 20746 & 180247 & 3,3 & 85,2 & 11,5 \\
\hline 2013 & 5589,6 & 140308 & 21756 & 167653 & 3,3 & 83,7 & 13,0 \\
\hline 2014 & 2519,7 & 108330 & 17894 & 128744 & 2,0 & 84,1 & 13,9 \\
\hline 2015 & 4349,7 & 75644 & 15260 & 95253 & 4,6 & 79,4 & 16,0 \\
\hline 2016 & 4426,6 & 75612 & 15195 & 95233 & 4,6 & 79,4 & 16,0 \\
\hline 2017 & 2521,5 & 92872 & 16190 & 111584 & 2,3 & 83,2 & 14,5 \\
\hline 2018 & 2870,9 & 104523 & 17947 & 125340 & 2,3 & 83,4 & 14,3 \\
\hline
\end{tabular}

Джерело: складено автором за [2]

Таблиця 2 - Аналіз відкритості національної економіки України за 2010-2018 рр., млн дол. США

\begin{tabular}{|l|c|c|c|c|c|c|c|c|}
\hline Роки & $\begin{array}{c}\text { Експорт } \\
\text { товарів і } \\
\text { послуг }\end{array}$ & $\begin{array}{c}\text { Імпорт } \\
\text { товарів і } \\
\text { послуг }\end{array}$ & $\begin{array}{c}\text { Зовнішньо- } \\
\text { торговельний } \\
\text { оборот }\end{array}$ & $\begin{array}{c}\text { Номіна- } \\
\text { льний } \\
\text { ВвП }\end{array}$ & $\begin{array}{c}\text { Коефіціснт } \\
\text { відкритості } \\
\text { економіки }\end{array}$ & $\begin{array}{c}\text { Імпортна } \\
\text { квота }\end{array}$ & $\begin{array}{c}\text { Ккспортна } \\
\text { квота }\end{array}$ & $\begin{array}{c}\text { цієнт } \\
\text { покриття } \\
\text { імпорту }\end{array}$ \\
\hline 2010 & 63341,5 & 66163,8 & 129505,3 & 136419 & 1,00 & 0,49 & 0,46 & 1,04 \\
\hline 2011 & 82574,5 & 88822,4 & 171396,9 & 163160 & 1,09 & 0,54 & 0,51 & 1,08 \\
\hline 2012 & 82926,6 & 91367,7 & 174294,3 & 175781 & 1,03 & 0,52 & 0,47 & 1,10 \\
\hline 2013 & 77553,9 & 84509,8 & 162063,7 & 183310 & 0,91 & 0,46 & 0,42 & 1,09 \\
\hline 2014 & 65422,5 & 60801,8 & 126224,3 & 131805 & 0,98 & 0,46 & 0,50 & 0,93 \\
\hline 2015 & 47863,7 & 43039,4 & 90903,1 & 90615 & 1,05 & 0,47 & 0,53 & 0,90 \\
\hline 2016 & 46229,7 & 44576,3 & 90806,0 & 93270 & 1,02 & 0,48 & 0,50 & 0,96 \\
\hline 2017 & 53979,0 & 55083,3 & 109062,3 & 112154 & 0,99 & 0,49 & 0,48 & 1,02 \\
\hline 2018 & 58972,9 & 63496,4 & 122469,3 & 130832 & 0,96 & 0,49 & 0,45 & 1,08 \\
\hline
\end{tabular}

Джерело: складено автором за даними [2; 4]

оподаткування та митного контролю над правильністю нарахування митних податків і платежів і повнотою їх сплати до державного бюджету.

Загалом аналіз зведеного зовнішньоторговельного балансу України за останні роки показав, що зовнішньоторговельна діяльність, що переважно характеризується операціями 3 експорту та імпорту товарів та послуг, $є$ занадто відкритою, що свідчить про залежність національної економіки від світового господарства, оскільки коефіцієнт відкритості економіки протягом останніх років знаходиться на межі $100 \%$ (табл. 2). Тоді як цей показник у розвинутих країнах значно менший: у США він становить лише $31 \%$, у Канаді $24 \%$, у Франції - 30,5\% у Китаї - 21\% [3].

Окрім того, аналіз зовнішньоторговельної діяльності України за останні роки показав, що коефіцієнт покриття імпорту (експортом) утримується близько значення 1,0. Проте більш детальний аналіз основних складників зовнішньоторговельного балансу в розрізі торгових операцій iз товарами та послугами показав, що в останні роки спостерігається тенденція з превалювання від'ємного сальдо за операціями зовнішньої торгівлі товарами, за якими коефіцієнт покриття в окремі роки сягає значення близько 1,2 , тобто імпорт майже на $20 \%$ перевищує експорт товарів (табл. 3), що свідчить про негативні тенденції розвитку зовнішньоекономічної діяльності в Україні.

Загалом за досліджуваний період спостерігаємо погіршення стану зовнішньоторговельної діяльності України в частині торгівлі товарами (окрім 2015 р., коли темпи скорочення імпорту товарів випередили темпи скорочення експорту, внаслідок чого було позитивне сальдо у розмірі 610,7 млн дол. США). Аналізуючи показники табл. 3, можна зробити висновки, що імпорт товарів та послуг протягом усього періоду перевищував експорт товарів та послуг. Зважаючи на той факт, що імпортні товари більш конкурентоспроможні, це завдає збитків національному товаровиробнику, проте водночас і стимулює його до модернізації виробництва.

Зважаючи на значне перевищення експорту послуг над їх імпортом та позитивне сальдо від торгівлі послугами й досить прийнятний показник покриття імпорту послуг - 0,44-0,57, загальноторговельне сальдо України у цілому має слабко виражений позитивний тренд. До того ж зауважимо, що в разі призупинення зростання 
від'ємного сальдо й з урахуванням середнього значення його зміни матиме тенденцію до вирівнювання загальноторговельного балансу. За результатами прогнозного аналізу 3 прив'язками до фактичних даних та визначення показників високої та низької ймовірності у найближчому майбутньому можуть справдитися як оптимістичні, так i песимістичні прогнози розвитку зовнішньоторговельної діяльності залежно від того, яку зовнішньоторговельну політику вибере уряд України та якою буде зовнішньоторговельна кон'юнктура у 2020-2022 рр. (табл. 4, рис. 1).

Зважаючи на мету нашого дослідження, визначимося, як обсяги зовнішньоторговельної діяльності впливають на формування доходної частини бюджету. Зазначимо, що левова частка податків та платежів у сфері зовнішньоторговельної діяльності сплачується імпортерами у вигляді податку на додану вартість (далі ПДВ) та акцизного податку на ввезені на митну територію України товари та транспортні засоби (табл. 5).

Таким чином, ми бачимо, що від стану зовнішньоторговельної діяльності країни залежить збалансованість державного бюджету, оскільки коефіцієнт концентрації податкових надходжень від зовнішньоторговельної діяльності у доходах державного бюджету є достатньо стабільним і високим та становить понад $374 \%$, а концентрація податків та платежів від ЗЕД у сумі податкових надходжень за останні п'ять років знаходиться у діапазоні 46,7-50,6\%, із них податки на імпорт наближаються до 100-відсоткового значення від оподаткування ЗЕД.

Тобто 3 позицій наповнення державного бюджету за кодами податкових надходжень зростання імпортної квоти є позитивним явищем, адже чим більшою є вартість імпортованих товарів, тим більше податків та платежів має надійти

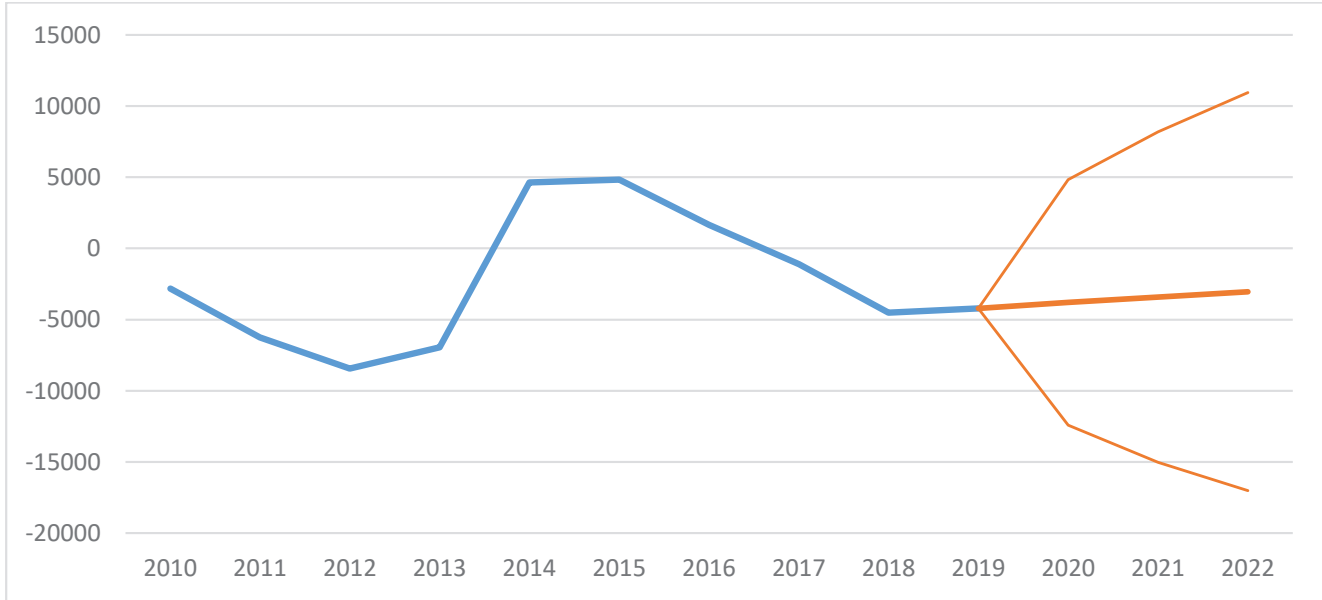

Примітки: - фактичні дані; - прогнозний тренд; - прив’язки ймовірності

Рисунок 1 - Прогнозний тренд формування зовнішньоторговельного сальдо України на 2020-2022 рр.

Таблиця 3 - Аналіз зовнішньоторговельного балансу за 2010-2018 рр., млн дол. США

\begin{tabular}{|c|c|c|c|c|c|c|c|c|c|}
\hline Роки & $\begin{array}{c}\text { Експорт } \\
\text { товарів }\end{array}$ & $\begin{array}{c}\text { Імпорт } \\
\text { товарів }\end{array}$ & $\begin{array}{c}\text { Сальдо } \\
\text { торгівлі } \\
\text { това- } \\
\text { рами }\end{array}$ & $\begin{array}{c}\text { Коеф. } \\
\text { покриття } \\
\text { імпорту } \\
\text { товарів }\end{array}$ & $\begin{array}{c}\text { Експорт } \\
\text { послуг }\end{array}$ & $\begin{array}{c}\text { Смпорт } \\
\text { послуг }\end{array}$ & $\begin{array}{c}\text { торгівлі } \\
\text { послу- } \\
\text { гами }\end{array}$ & $\begin{array}{c}\text { покриття } \\
\text { імпорту } \\
\text { послуг }\end{array}$ & $\begin{array}{c}\text { Зовнішньо- } \\
\text { торгове- } \\
\text { льне сальдо }\end{array}$ \\
\hline 2010 & 51405,2 & 60742,2 & $-9337,0$ & 1,18 & 11936,3 & 5421,6 & 6514,7 & 0,45 & $-2822,3$ \\
\hline 2011 & 68394,2 & 82608,2 & $-14214,0$ & 1,21 & 14180,3 & 6214,2 & 7966,1 & 0,44 & $-6247,9$ \\
\hline 2012 & 68830,4 & 84717,6 & $-15887,2$ & 1,23 & 14096,2 & 6650,1 & 7446,1 & 0,47 & $-8441,1$ \\
\hline 2013 & 63320,7 & 76986,8 & $-13666,1$ & 1,22 & 14233,2 & 7523,0 & 6710,2 & 0,53 & $-6955,9$ \\
\hline 2014 & 53901,7 & 54428,7 & $-527,0$ & 1,01 & 11520,8 & 6373,1 & 5147,7 & 0,55 & 4620,7 \\
\hline 2015 & 38127,1 & 37516,4 & 610,7 & 0,98 & 9736,6 & 5523,0 & 4213,6 & 0,57 & 4824,3 \\
\hline 2016 & 36361,7 & 39249,8 & $-2888,1$ & 1,08 & 9868,0 & 5326,5 & 4541,5 & 0,54 & 1653,4 \\
\hline 2017 & 43264,7 & 49607,2 & $-6342,5$ & 1,15 & 10714,3 & 5476,1 & 5238,2 & 0,51 & $-1101,3$ \\
\hline 2018 & 47335,0 & 57187,6 & $-9852,6$ & 1,21 & 11637,9 & 6308,8 & 5329,1 & 0,54 & $-4523,5$ \\
\hline $2019 *$ & 50141,8 & 60367,6 & 10225,8 & 1,20 & 11935,6 & 6298,8 & 5637,8 & 0,53 & $-4588,0$ \\
\hline
\end{tabular}

Джерело: складено автором за даними [2; 5] 
Таблиця 4 - Розрахунок прогнозного тренду формування

зовнішньоторговельного сальдо України на 2020-2022 pp.

\begin{tabular}{|c|c|c|c|c|}
\hline Часова шкала & Значення & Прогноз & $\begin{array}{c}\text { Прив'язка низької } \\
\text { ймовірності }\end{array}$ & $\begin{array}{c}\text { Прив'язка високої } \\
\text { ймовірності }\end{array}$ \\
\hline 2010 & $-2822,3$ & & & \\
\hline 2011 & $-6247,9$ & & & \\
\hline 2012 & $-8441,1$ & & & \\
\hline 2013 & $-6955,9$ & & & \\
\hline 2014 & 4620,7 & & & \\
\hline 2015 & 4824,3 & & & \\
\hline 2016 & 1653,4 & & & \\
\hline 2017 & $-1101,3$ & & & $-4588,00$ \\
\hline 2018 & $-4523,5$ & & $-4588,00$ & 4477,06 \\
\hline $2019 *$ & $-4588,0$ & $-4588,0$ & $-12783,99$ & 7815,10 \\
\hline 2020 & & $-4153,4638$ & $-15418,83$ & 10533,86 \\
\hline 2021 & & $-3801,8662$ & $-17434,40$ & \\
\hline 2022 & & $-3450,2686$ & & \\
\hline
\end{tabular}

*_ показники за 2019 р. розраховані на підставі статистичних даних за 11 місяців 2019 р.

Докерело: складено автором за даними [2; 6]

Таблиця 5 - Структура надходжень до державного бюджету України за 2016-2019 рр.

\begin{tabular}{|c|c|c|c|c|c|c|c|c|c|c|}
\hline \multirow[b]{2}{*}{ Показники } & \multicolumn{2}{|c|}{2015 p. } & \multicolumn{2}{|c|}{2016 p. } & \multicolumn{2}{|c|}{2017 p. } & \multicolumn{2}{|c|}{2018 p. } & \multicolumn{2}{|c|}{2019 p. } \\
\hline & $\begin{array}{c}\text { млрд } \\
\text { грн }\end{array}$ & $\%$ & $\begin{array}{c}\text { млрд } \\
\text { грн }\end{array}$ & $\%$ & $\begin{array}{c}\text { млрд } \\
\text { грн }\end{array}$ & $\%$ & $\begin{array}{c}\text { млрд } \\
\text { грн }\end{array}$ & $\%$ & $\begin{array}{c}\text { млрд } \\
\text { грн }\end{array}$ & $\%$ \\
\hline Доходи, всього & 534,7 & 100 & 616,3 & 100 & 793,3 & 100 & 928,1 & 100 & 998,3 & 100 \\
\hline Податкові надходження & 409,4 & 76,6 & 503,9 & 81,8 & 627,2 & 79,1 & 753,8 & 81,2 & 799,8 & 80,1 \\
\hline $\begin{array}{l}\text { Податки на } \\
\text { зовнішньоторговельні } \\
\text { операції: }\end{array}$ & 203,4 & 38,0 & 236,9 & 38,4 & 317,1 & 40,0 & 370,2 & 39,8 & 373,4 & 37,4 \\
\hline - акциз на ввезені товари & 24,3 & 4,6 & 35,0 & 5,7 & 42,0 & 5,3 & 47,7 & 5,1 & 53,5 & 5,4 \\
\hline - ПДВ на ввезені товари & 138,8 & 25,9 & 181,5 & 29,4 & 250,5 & 31,6 & 295,4 & 31,8 & 289,8 & 29,0 \\
\hline $\begin{array}{l}\text { - податки на міжнародну } \\
\text { торгівлю й зовнішні } \\
\text { операції, з них: }\end{array}$ & 40,3 & 7,5 & 20,4 & 3,3 & 24,5 & 3,1 & 27,1 & 2,92 & 30,1 & 3,01 \\
\hline ввізне мито & 39,9 & 7,46 & $19,7-$ & 3,2 & 23,9 & 3,0 & 26,6 & 2,86 & 29,9 & 2,99 \\
\hline вивізне мито & 0,4 & 0,04 & 0,7 & 0,1 & 0,6 & 0,1 & 0,5 & 0,06 & 0,2 & 0,02 \\
\hline $\begin{array}{l}\text { Податкові надходження від } \\
\text { iмпорту товарів }\end{array}$ & 203,0 & 37,96 & 236,2 & 38,3 & 316,5 & 39,9 & 369,7 & 39,74 & 373,2 & 37,38 \\
\hline $\begin{array}{l}\text { Концентрація податків } \\
\text { від ЗЕД у сумі податкових } \\
\text { надходжень, \% }\end{array}$ & $\mathrm{x}$ & 49,4 & $\mathrm{x}$ & 47,0 & $\mathrm{x}$ & 50,6 & $\mathrm{x}$ & 49,1 & $\mathrm{x}$ & 46,7 \\
\hline $\begin{array}{l}\text { Концентрація податків } \\
\text { на ввезені товари у сумі } \\
\text { податкових надходжень від } \\
\text { ЗЕД, \% }\end{array}$ & $\mathrm{x}$ & 99,8 & $\mathrm{x}$ & 99,7 & $\mathrm{x}$ & 99,8 & $\mathrm{x}$ & 99,9 & $\mathrm{x}$ & 99,9 \\
\hline
\end{tabular}

Джерело: складено автором за даними [4; 5]

до бюджету. При цьому, як видно 3 табл. 5, майже $40 \%$ від суми доходів, або майже 50\% від податкових надходжень до бюджету, становлять податки та платежі, що сплачуються суб'єктами ЗЕД у вигляді непрямих податків під час перетину товарами та транспортними засобами митного кордону України. Тому під час аналізу ефективності діяльності митних органів варто більш детально зупинитися не лише на питаннях адміністрування митних податків і платежів, а й на питаннях ухилення від оподаткування імпортерами та забезпечення ефективності митного контролю щодо їх нарахування та сплати.

Окрім того, аналіз динаміки надходжень податків та платежів від зовнішньоторговельних операцій до державного бюджету України за останні п'ять років (табл. 5) свідчить про тенденцію до щорічного збільшення митних платежів. 
Так, у 2015 р. це 203,4 млрд грн, а вже у 2019 р. 373,4 млрд грн, що більше на 170 млрд грн, або майже на $184 \%$. 3 іншого боку, зважаючи, що курс долара у 2015 р. був 21,85 грн, а в 2019 р. 26,51 грн, у доларовому еквіваленті отримаємо, що у 2015 р. до державного бюджету України від зовнішньої торгівлі надійшло 9,309 млрд дол., а в 2019 p. - 14,085 млрд дол. Тобто приріст податкових надходжень у 2019 р. до 2015 р. становив $4,776,3$ млрд дол., або $151,3 \%$, у середньому більше 10\% щорічно (табл. 6). Перш за все це пов'язано зі збільшенням обсягів імпорту та його вартості у доларовому еквіваленті.

Проте якщо зважити на те, що приріст імпорту товарів із 2015 до 2019 р. становив 160,9 \%, то можна зробити два висновки:

по-перше, що всі митні платежі, окрім ПДВ, несуть не фіскальне навантаження, а скоріше мають регулятивну, контролюючу та захисну функції, про це свідчить і тенденція до зниження податкового навантаження на імпорт 324,75 у 2015 р. до 23,32 у 2019 р. на $1,43 \%$;

по-друге, що держава втрачає певну суму надходжень від послаблення фіскальної функції й зменшення податкового навантаження, а також наявності значної кількості преференційних товарів, що надходять до України за пільговими ставками оподаткування. Так, лише за умови дотримання податкового навантаження на рівні 2015 p. до бюджету додатково надійшло б 5336,8 млн грн.

Загалом, якщо аналізувати темпи приросту надходжень, то значне збільшення зафіксовано у 2017 та 2018 рр. завдяки вжиттю ефективних заходів, спрямованих на здійснення належної організації митного контролю, ефективної протидії митним правопорушенням, забезпечення повноти оподаткування товарів, достовірності декларування товарів, транспортних засобів, що переміщуються через митний кордон України, посилення роботи 3 контролю над правильністю визначення митної вартості товарів, класифікації країни походження. Так, у 2017 р. митницями ДФС зібрано до бюджету 316,5 млрд грн від імпорту товарів, або на 80,3 млрд грн (28,6\%) більше, ніж у 2016 р., а в
2018 р. абсолютний приріст податків з імпорту становив 63,2 млрд грн $(15,3 \%)$ до показників 2017 р.

Нині спостерігається тенденція до майже пропорційного зростання обсягів зовнішньої торгівлі, імпорту товарів і надходжень від митних платежів до державного бюджету. Лише у 2016 р. відбувся незначний спад: надходження від митних платежів порівняно з 2015 р. зменшилися на $0,5 \%$, що в доларовому еквіваленті становило 41,8 млн дол. Такий спад можна пов'язати зі зростанням курсу долара, а також зі зменшенням податкового тиску на бізнес унаслідок оптимізації ставок митних платежів відповідно до європейських норм. Обрахування митного навантаження, яке виглядає як відношення митних платежів, зібраних до ДБУ, та номінального ВВП, указує на незначне коливання рівня митного навантаження від 9,9\% до $10,6 \%$. У 2016 р. надходження від мита зменшилися у зв'язку зі зниженням обсягу імпорту в Україну з Росії та повільними темпами виходу на зовнішні ринки. Щодо 2017 та 2018 рр., то вони були досить удалими для розвитку зовнішньоторговельної діяльності України, яка почала активно освоювати азійський та африканський напрямки, що дало змогу суттєво збільшити обсяги імпорту товарів та податкові надходження від нього.

Однак приріст надходжень податків від імпорту до державного бюджету у 2019 р. був найменшим за останні три роки й порівняно з 2018 р. становив лише 3,6\%, або 3,5 млрд грн (за збільшення імпорту на 5,6\%), тоді як у 2018 р. темпи приросту митних податків з імпорту становили $14,3 \%$, що в абсолютному значенні дорівнювало 53,2 млрд грн. Основними причинами суттєвого зниження приросту обсягів легального імпорту, а отже, й податкових надходжень до бюджету від митних податків та платежів, стали: по-перше, реформування фіскальної системи України, що практично паралізувало діяльність митної служби більше ніж на півроку та призвело до активізації тіньового сектору; по-друге, все більша формалізація процедури митного контролю під час митного оформлення та його відсутність після випуску товарів у вільний обіг, що призвело до зменшення його ефективності.

\section{Таблиця 6 - Аналіз податкових надходжень та податкового навантаження} на операції з імпорту товарів за 2015-2019 рр.

\begin{tabular}{|c|c|c|c|c|c|c|c|}
\hline \multirow{2}{*}{ Роки } & \multirow{2}{*}{$\begin{array}{c}\text { Податки } \\
\text { на імпорт } \\
\text { товарів, } \\
\text { млрд грн }\end{array}$} & \multirow{2}{*}{$\begin{array}{c}\text { Середньо- } \\
\text { річний } \\
\text { курс, } \\
\text { дол./грн }\end{array}$} & \multirow{2}{*}{$\begin{array}{c}\text { Податки } \\
\text { на імпорт } \\
\text { товарів, } \\
\text { млн дол. }\end{array}$} & \multirow{2}{*}{$\begin{array}{c}\text { Обсяги } \\
\text { імпорту } \\
\text { товарів, } \\
\text { млн дол. }\end{array}$} & \multicolumn{2}{|c|}{$\begin{array}{c}\text { Темпи росту, до } \\
\text { попереднього року \% }\end{array}$} & \multirow{2}{*}{$\begin{array}{c}\text { Податкове } \\
\text { навантаження } \\
\text { до номінального, } \\
\text { ВВП\% }\end{array}$} \\
\hline & & & & & $\begin{array}{l}\text { податкових } \\
\text { надходжень }\end{array}$ & $\begin{array}{l}\text { обсягів } \\
\text { імпорту }\end{array}$ & \\
\hline 2015 & 203,0 & 21,86 & 9286,4 & 37516,4 & 100,0 & 100,0 & 10,2 \\
\hline 2016 & 236,2 & 25,55 & 9244,6 & 39249,8 & 99,5 & 104,6 & 9,9 \\
\hline 2017 & 316,5 & 26,62 & 11889,6 & 49607,2 & 128,6 & 126,4 & 10,6 \\
\hline 2018 & 369,7 & 27,20 & 13591,9 & 57187,6 & 114,3 & 115,3 & 10,4 \\
\hline 2019 & 373,2 & 26,51 & 14077,7 & 60367,6 & 103,6 & 105,6 & 10,4 \\
\hline
\end{tabular}

Джерело: розраховано автором за даними [2; 4-6] 
Загалом варто відзначити, що в Україні дійсно $є$ певні позитивні зрушення у напрямі спрощення митних процедур, зокрема підвищення ефективності митного контролю за рахунок використання ризикоорієнтованих підходів та застосування процедури попереднього декларування та е-декларування. Але ці позитивні зміни переважно спрямовані на полегшення та пришвидшення процедури митного оформлення для добросовісних платників податків. Про результативність такої діяльності свідчать суми додаткових платежів, що надходять до бюджету від здійснення митного контролю. Так, митницями ДФС за період 2015-2018 рр. було забезпечено виконання низки заходів щодо контролю правильності визначення митної вартості товарів, проте ефективність таких заходів має тенденцію до зменшення. Так, якщо сума додаткових надходжень коштів від корегування митної вартості у 2015 р. становила 5,3 млрд грн, то у 2016 р. додатково від коригування митної вартості імпорту товарів до бюджету було отримано вже 4,6 млрд грн, у 2017 4,0 млрд грн і тільки у 2018 р. - 5,0 млн грн, що менше, ніж у 2015 p. [8].

Зазначимо, що за рахунок коригування митної вартості товарів у 2018 р. було забезпечено близько 94,5\% додаткових надходжень до державного бюджету. Зниження даного показника, за даними митної служби, пов'язане зі зміною структури імпорту та заміною більш дорогих товарів їх дешевими аналогами, зміною цін на зовнішніх ринках, застосуванням митних тарифів відповідно до Угоди про асоціацію між Україною та ЄС.

Найбільш дієвим інструментом протидії тим суб' єктам ЗЕД, хто ухиляється від сплати податків та платежів шляхом здійснення імпортних операцій або ж поза митним контролем, або ж 3 приховуванням від митного контролю, є впровадження митного аудиту, який, на жаль, в Україні реально так і не застосовується. До того ж досі у митному законодавстві не визнано митний аудит та не визначено його роль і місце в системі митного контролю. I сьогодні у затвердженій структурі центрального апарату відновленої Державної митної служби України передбачено створення Управління організації митного аудиту, що, на жаль, відірване від Департаменту організації митного контролю, а реальний запуск діяльності цього інституту заплановано тільки на кінець 2020 р. [9]. Ці інституційні недоліки негативно впливають на ефективність митного контролю над зовнішньоторговельними операціями, що забезпечують податкові надходження до бюджету й вимагають нагального викорінення.

Висновки. Таким чином, аналіз стану податків та платежів щодо оподаткування зовнішньоекономічної діяльності в Україні дав можливість 3'ясувати, що у структурі податкових надходжень від ЗЕД превалюють митні податки та платежі, що нараховуються на операції з імпорту товарів. При цьому обгрунтовано, що в останні роки митні платежі виконують переважно фіскальну функцію, а не регулюючу. Серед основних проблем використання регулюючого потенціалу митних платежів варто виділити часті випадки заниження митної вартості суб' єктами ЗЕД під час здійснення імпортних операцій, про що свідчать і результати митного контролю правильності визначення митної вартості. Для усунення зазначеної проблеми необхідно не лише налагодити активну співпрацю між суб'єктами ЗЕД та митними органами, а також митними органами зарубіжних країн, а й кардинально змінити підходи до формування та реалізації митної політики. При цьому значну увагу варто приділити питанням удосконалення організації митного контролю та посилення контрольної функції з одночасним збереженням заходів, спрямованих на спрощення митних процедур. Досягнення даної мети можливе за умови реального впровадження в Україні ризикоорієнтованого митного аудиту, що потребує додаткових досліджень і може бути висвітлено у наступних статтях.

\section{Список використаних джерел:}

1. Про зовнішньоекономічну діяльність : Закон України від 16.04.1991 № 959-XII. URL : https://zakon.rada.gov.ua/ laws/show/959-12 (дата звернення: 12 грудня 2019 р.).

2. Офіційний вебсайт Державного комітету статистики України. URL : http://www.ukrstat.gov.ua (дата звернення: 25 грудня 2019 р.).

3. Офіційний вебсайт Всесвітньої торгової організації. URL : http://www.wto.org (дата звернення: 13 листопада 2019 p.).

4. Показники виконання бюджету України за 2010-2018 рр. : офіційний вебсайт Міністерства фінансів України. URL : http://www.minfin.gov.ua/control/uk/publish/archive/main?cat_id =77643 (дата звернення: 2 липня 2019 р.).

5. Державні фінанси: Доходи держбюджету України : офіційний сайт Міністерства фінансів України. URL : https://index.minfin.com.ua/finance/ budget/gov/income/ (дата звернення: 6 грудня 2019 р.).

6. Бюджетний моніторинг: аналіз виконання бюджету за січень-жовтень 2019 року: / І.Ф. Щербина та ін. ; ІБСЕД, Проєкт «Зміцнення місцевої фінансової ініціативи (ЗМФI-II) впровадження», USAID. Київ, 2012. 71 с.

7. Офіційний вебсайт Державної фіскальної служби України. URL : http://sfs.gov.ua/ (дата звернення: 2 грудня 2019 р.).

8. Звіт Державної фіскальної служби України за 2018 p. URL : http://sfs.gov.ua/data/files/240396.pdf (дата звернення: 2 липня 2019 р.).

9. Минфин утвердил структуру главного аппарата новой таможни и штатное расписание. URL https://www.epravda.com.ua/rus/news/2019/ 09/2/651178/ (дата звернення: 25 жовтня 2019 р.). 


\section{References:}

1. Verkhovna Rada of Ukraine (1991) The Law of Ukraine «On Foreign Economic Activity», avialable at: https://zakon.rada.gov.ua/laws/show/959-12 (accessed 12 December, 2019)

2. Official web-site of the State Statistics Committee of Ukraine. avialable at: http://www.ukrstat.gov.ua (Accessed 25 December, 2019)

3. Official website of the World Trade Organization. URL: http://www.wto.org (accessed 13 November, 2019)

4. Ministry of Finance of Ukraine (2019) Budget Performance Indicators for 2010-2018 Official Website of the? avialable at: http://www.minfin.gov.ua/control/uk /publish/archive/main?Cat id=77643 (accessed 2 July, 2019)

5. Ministry of Finance of Ukraine (2019) Public Finances: State Budget Revenues. Official site of the Ministry of Finance of Ukraine. avialable at: https://index.minfin.com.ua/finance/ budget / gov / income / (accessed 6 December, 2019)

6. Shcherbina IF, Rudik A. Yu., Zubenko VV, etc (2012) Byudzhetnyy monitorynh: analiz vykonannya byudzhetu za sichen' zhovten' 2019 roku [Budget Monitoring: Analysis of Budget Execution for January - October 2019]; IBSER, Local Financial Initiative Strengthening (MFI-II) Implementation Project, USAID. Kyiv, 71 p. [Ukraine].

7. Official website of the State Fiscal Service of Ukraine. avialable at: http://sfs.gov.ua/ (accessed 2 December, 2019)

8. State Fiscal Service of Ukraine (2019) Report of the State Fiscal Service of Ukraine for 2018. avialable at: http://sfs.gov.ua/data/files/240396.pdf (accessed 2 July, 2019)

9. Mynfyn utverdyl strukturu hlavnoho apparata novoy tamozhny y shtatnoe raspysanye [The Ministry of Finance approved the structure of the main office of the new customs and staffing], avialable at: https://www.thoughda.com.ua/ eng/news/2019/ 09/2/651178 / (accessed 25 October, 2019).

Menliosmanov Zair

University of the State Fiscal Service of Ukraine

\section{ANALYSIS AND CONTROL OF TAX REVENUE TO THE BUDGET OF UKRAINE FROM FOREIGN ECONOMIC ACTIVITIES}

The restoration of Ukraine's socio-economic potential and its financial stability depends on sound budgetary policies and timely filling of the state treasury with taxes. The amount of tax revenues from foreign trade activity is currently almost half of the state budget. It is relevant to analyze the structure and dynamics of Ukraine's foreign trade volumes and their impact on the formation of tax revenues to the budget. Customs control over ensuring the completeness of customs taxes and payments by FEA entities is of great importance. The paper uses a systematic approach and methods of economic and financial analysis, in particular, methods of analysis of series of dynamics, estimation of absolute and relative values of growth rates, comparison of statistical indicators on the volumes of foreign trade operations and customs taxes and payments for them for 2010 - 2019. This made it possible to justify the results obtained and to make sound conclusions. The article analyzes the structure of foreign economic activity, the current state of foreign trade activity in Ukraine. The openness of the national economy in recent years has also been assessed. The tendencies of development of operations on import of goods and receipts of customs taxes and payments to the state budget over the last ten years are highlighted. It is justified that in recent years, customs payments are mainly a fiscal function rather than a regulatory one. The indicators of foreign trade balance were evaluated and the main factors of formation of a negative foreign trade balance were determined. According to the results of the study, the ways of increasing the efficiency of taxation in the sphere of foreign trade are substantiated. The main indicators of the effectiveness of customs control in terms of formation of additional payments to the budget from adjusting the customs value. Prospects of increase of additional revenues to the budget on the basis of improvement of methods of customs control of the value of imported goods are determined. It is proposed to change the approaches to the formation and implementation of customs policy on the basis of improving the organization of customs control and strengthening of the control function, while maintaining measures aimed at simplifying customs procedures.

Key words: foreign trade activity, import of goods, foreign trade balance, customs taxes and payments, customs control.

JEL classification: E62, F14, H21, H22, H25, H60. 